\title{
Ageing in individuals with intellectual disability: issues and concerns in Hong Kong
}

\author{
Mimi MY Tse *, Rick YC Kwan, Joyce L Lau
}

\section{A B S T R A C T}

Introduction: The increasing longevity of people with intellectual disability is testimony to the positive developments occurring in medical intervention. Nonetheless, early-onset age-related issues and concerns cause deterioration of their overall wellbeing. This paper aimed to explore the issues and concerns about individuals with intellectual disability as they age.

Methods: Articles that discussed people older than 30 years with an intellectual disability and those that identified ageing health issues and concerns were included. Only studies reported in English from 1996 to 2016 were included. We searched PubMed, Google Scholar, and Science Direct using the terms 'intellectual disability', 'ageing,' 'cognitive impairment', 'health', and 'screening'.

Results: Apart from the early onset of age-related health problems, dementia is more likely to develop by the age of 40 years in individuals with intellectual disability. Geriatric services to people with intellectual disability, however, are only available for those aged 60 years and older. Cognitive instruments used for the general population are not suitable for people with intellectual disability because of floor effects. In Hong Kong, the Chinese version of the Dementia Screening Questionnaire for Individuals with Intellectual Disabilities is the only validated instrument for people with intellectual disability. The use of appropriate measurement tools to monitor the progression of age-related conditions in individuals with intellectual disability is of great value.

Conclusions: Longitudinal assessment of cognition and function in people with intellectual disability is vital to enable early detection of significant deterioration. This allows for therapeutic intervention before substantial damage to the brain occurs such as dementia that hastens cognitive and functional decline.

Hong Kong Med J 2018;24:68-72

DOI: 10.12809/hkmj166302

MMY Tse *, PhD

RYC Kwan, PhD

JL Lau, MSc

School of Nursing, The Hong Kong Polytechnic University, Hung Hom, Hong Kong

* Corresponding author: mimi.tse@polyu.edu.hk

\section{Introduction}

Over the past half-century, the life expectancy of individuals with intellectual disability (ID) has increased. Intellectual disability is defined as a disorder with onset before the age of 18 years that includes both intellectual and adaptive functioning deficits in conceptual, social, and practical domains. ${ }^{1}$ The deficits prevent an individual from performing activities of daily living independently. Therefore, ID places a great burden not only on the individual but also on the caregiver and health care services. ${ }^{2}$ International studies report that 4.94 per 1000 adults globally have an ID. ${ }^{3}$ In Hong Kong, it is estimated that there are about 67000 to 80000 people with ID. ${ }^{4}$

An increased life expectancy may be accompanied by negative health outcomes such as obesity, osteoporosis, and cataract in people with ID and results in an early onset of age-related health conditions. ${ }^{5,6}$ Indeed, the incidence of these health conditions is rising and is higher than in non-ID individuals. ${ }^{7}$ In addition, by the age of 40 years, people with ID are more likely to develop dementia, as their cognition declines faster compared with their non-ID counterparts. ${ }^{8,9}$

Alzheimer's disease (AD) is the most common form of dementia with symptoms that are severe enough to cause serious health deterioration. Affected individuals become increasingly dependent on caregivers and have an increased likelihood of institutionalisation. ${ }^{6,10}$ It is reported that $\mathrm{AD}$ has a strong association with Down's syndrome (DS), ${ }^{6}$ which is the most commonly known genetic cause of ID, diagnosed in approximately 14 of 10000 live births. ${ }^{11}$ It is associated with characteristic physical features, deficits in the immune and endocrine systems, and delayed cognitive development.

The prevalence of $\mathrm{AD}$ in $\mathrm{DS}$ varies between studies..$^{12}$ Wiseman et $\mathrm{al}^{13}$ reported that approximately $5 \%$ to $15 \%$ of people with DS aged 40 to 49 years and more than $30 \%$ of those aged 50 to 59 years experience a significant decline in their cognition, indicating dementia. McCarron et $\mathrm{al}^{14}$ reported that $68 \%$ to $80 \%$ of people with DS have developed dementia by the age of 65 years. 
The increasing longevity of people with ID is testimony to positive developments in medical intervention. Early-onset ageing issues and concerns, however, may further deteriorate overall well-being. To date, no study has examined the effects of ageing in people with ID in Hong Kong. This paper explored the issues and concerns surrounding people with ID as they age.

\section{Methods}

A search of the literature was conducted to identify the issues and concerns faced by individuals with ID. All articles about individuals older than 30 years with an ID, and those that identified ageing health issues and concerns were included. The search was restricted to articles published in English between 1996 and 2016. Databases of PubMed, Google Scholar, and Science Direct were searched. Keywords used were 'intellectual disability', 'ageing,' 'cognitive impairment', 'health', and 'screening.'

\section{Results}

Three major issues emerged: insufficient services and accommodation, cognitive screening, and lack of intervention to delay cognitive and health deterioration in individuals with ID.

\section{Insufficient services and accommodation}

As individuals with ID live longer, their demand for residential services has increased. ${ }^{15}$ This growing demand has led to longer waiting times and an increased burden on caregivers. ${ }^{16}$

Pang's survey ${ }^{7}$ determined that there are insufficient government services and accommodation for individuals with ID in Hong Kong. Of 2159 eligible participants, only 1865 were catered for. Discrepancies in the prevalence reports by the government and non-governmental organisations (NGOs) in the field have also been reported. Government statistics have reported 67000 to 80000 individuals with ID in Hong Kong, but NGOs place this figure at 100000 . This huge difference suggests that a significant proportion of affected individuals are not receiving support services from the government. ${ }^{7}$

Moreover, geriatric services to individuals with ID are only available from the age of 60 years. Since individuals with ID face ageing at an earlier age, there is clearly insufficient access to health services and health promotion activities for this population. This further contributes to the rapid decline of their health, especially cognition. ${ }^{17}$

\section{Cognitive screening of individuals with intellectual disability}

Diagnosing the presence of significant cognitive deterioration such as dementia among individuals

\section{香港智障人士老齡化：問題與關注事項 謝敏儀、關耀祖、Joyce L Lau}

引言：隨着醫療技術不斷進步, 智障人士的壽命越來越長。儘管如 此, 智障人士早發性老化的現象令他們的整體健康情況惡化。本文旨 在探討智障人士隨着年齡增長而出現的問題, 以及我們必須關注的事 項。

方法：本文選取討論 30 歲以上智障人士，以及有關老齡化健康問 題和關注事項的文獻。我們利用以下關鍵詞搜索PubMed、Google Scholar和Science Direct數據庫的資料：「智力障礙」（intellectual disability ）、「老齡化」（ageing）、「認知功能障礙」（ cognitive impairment ）、「健康」（health）和 $「$ 篩檢」（screening）。搜索 範圍包括1996年至2016年出版的英文文獻。

結果：智障人士除了可能出現的早發性老齡化現象外, 40歲前出現失 智症的可能性更大。然而, 提供給智障人士的安老服務只適用於 60 歲 以上的患者。用於一般人士的認知檢測工具, 因低限效應的關係, 並 不適合智障人士。智障人士失智症篩選問卷的中文版是唯一一個適合 智障人士並經驗證的測量工具。使用適當的測量工具來鑑測智障人士 與年齡相關狀況的發展有重大價值。

結論：縱向評估智障人士的認知功能, 對於早期發現以防止惡化成其 他嚴重疾病至為重要。這樣才能在他們腦部出現嚴重損傷（如失智症 至加快認知和功能下降) 前進行治療性干預。

with ID is a challenge. This is because their level of cognition is already below-average. ${ }^{18,19}$ Nonstandardised screening instruments, risk factors, and lack of diagnostic criteria add to the difficulty of diagnosing dementia among individuals with ID.

\section{Non-standardised screening instrument}

Cognitive screening tools such as the Mini-Mental State Examination that is used in the general population are unsuitable for individuals with ID because of floor effects and the absence of standard cut-off thresholds. ${ }^{20}$ This may result in underdiagnosis of dementia cases. ${ }^{21,22}$ In addition, late symptoms of dementia that are present in the general population are experienced by individuals with ID at an early stage. When the diagnosis is made, people with ID are already at the late stage of dementia.

Similar to previous studies, screening of cognitive level of individuals with ID in Hong Kong is lacking. ${ }^{18,19,23}$ A recent study developed and validated the first cognitive assessment instrument for the Chinese population-the Chinese version of the Dementia Screening Questionnaire for Individuals with Intellectual Disabilities (DSQIID). ${ }^{18}$ Approximately 200 individuals with ID (mean age, 51 years) joined the study. The results showed good internal consistency for all 53 items, and excellent test-retest reliability and inter-rater reliability. Individuals who scored $\geq 22$ were likely to have a positive diagnosis of dementia. Those who scored 
$<22$ were considered to have cognitive and functional decline but of insufficient severity to be classified as dementia. The decline could be aged-related or due to other causes such as environmental factors. It is nevertheless important to remember that DSQIID is a screening instrument and not diagnostic. ${ }^{18}$

\section{Risk factors for dementia in individuals with intellectual disability}

$\operatorname{Sex}$

Sex has a strong correlation with the development of dementia in individuals with ID. It has been reported that women are more likely to develop dementia than men. This is because of the suboptimal level of oestrogen in women. ${ }^{24}$ Patel et $\mathrm{al}^{25}$ reported that an increased level of bioavailable oestradiol can reduce the risk of dementia and also result in better neuropsychological function. On the contrary, Farrer et $\mathrm{al}^{26}$ and Schupf et $\mathrm{al}^{27}$ found that women were at decreased risk of dementia. This contradictory result might have been due to different age ranges of the study participants.

\section{Oxidative damage}

In individuals with DS, the enzyme superoxide dismutase is present with increased activity. This enzyme plays a role in the free-radical-mediated damage that occurs when there is an imbalance between free radical production and cellular antioxidant defences. In addition, inflammatory factors such as S100B overexpression increase the risk of having dementia. A combination of these two factors can accelerate the progression to dementia in individuals with DS aged 40 years and older. ${ }^{24}$

\section{Genetic predisposition}

Given that there are a variety of conditions that can cause cognitive and behavioural changes in individuals with DS, especially as they age, it would be of great value to identify the genetic factors involved in differential diagnoses. ${ }^{28}$ Apolipoprotein $\mathrm{E}(A P O E) \varepsilon 4$ allele, and high levels of $\mathrm{A} \beta 1-42$ peptide have been reported to be associated with the onset of dementia in DS. ${ }^{29}$ Mok et $\mathrm{al}^{30}$ suggested that there are three variants in $B A C E 2$ that possibly affect the age of onset of dementia in DS, while Jones et $\mathrm{al}^{31}$ reported the involvement of PICALM and APOE loci in the process.

Nonetheless, some studies have found that the $A P O E \& 2$ allele decreases the risk of dementia in individuals with ID, although the sample sizes might have been too small to demonstrate a significant effect. $^{32-34}$

\section{Telomere shortening}

Apart from the above-mentioned genes, Jenkins et $\mathrm{al}^{28}$ reported that the telomeres of chromosomes 21 , 1,2 , and 16 are shorter in adults with DS and with either dementia or cognitive impairment compared with the general population. This finding suggests that telomere shortening can be used as a biomarker for inferring dementia.

\section{High cholesterol level}

A number of studies suggest a relationship between high serum cholesterol and increased risk of AD in individuals with ID. ${ }^{35-37}$ High cholesterol level increases the neural beta-amyloid load and the numbers of neuritic plaques and tangles that are characteristic of AD. ${ }^{38,39}$ Both factors are known to be elevated in people with ID. Zigman et $\mathrm{al}^{37}$ found that use of statin to lower cholesterol level decreased the risk of AD. Patel et $\mathrm{al}^{25}$ reported that high body mass index significantly decreased the risk of AD. This is because high body mass index is related to increased bioavailability of oestradiol and better neuropsychological function.

\section{Lack of diagnostic criteria to diagnose dementia in individuals with intellectual disability}

Nieuwenhuis-Mark ${ }^{40}$ has recommended measures to identify cognitive decline in people with ID such as clinical interviews, standard laboratory tests, neuroimaging, and cognitive testing. Nonetheless these are only guidelines. To date, no clear diagnostic criteria and assessment have been defined. This also explains the variation in the dementia prevalence from the published literature and further adds to the difficulty in identifying the presence of dementia.

\section{Lack of intervention to delay cognitive and health deterioration in individuals with intellectual disability}

Pang's survey ${ }^{7}$ found that $6.5 \%$ of those with ID had more than three co-morbid disabilities and $7.3 \%$ had more than three chronic medical conditions such as hypertension and cataract. Of those surveyed, $19.9 \%$ were admitted to an advanced sheltered home. The findings of the survey showed that people with ID experienced age-related health problems at an earlier age.

Heller et al's review ${ }^{41}$ summarised the effectiveness of health promotion interventions in people with ID without dementia and normal ageing adults. Despite searching 20 years of literature, only 25 ID studies were identified compared with 153 studies of ageing. The most common intervention that had a positive effect in individuals with ID was exercise. The review showed that there is limited research in the field of ageing adults with ID. It also concluded that individuals with ID are not included in the majority of health programmes for the ageing population. 
Multicomponent interventions in normal ageing adults have demonstrated good physical, health, and psychosocial outcomes. There has been only one study in individuals with ID and dementia. After the 3-year study intervention, there was some improvement in cognition, stabilisation, and behaviour in the experimental group compared with the control group. ${ }^{42}$

\section{Discussion}

The early onset of age-related health conditions in individuals with ID, especially dementia, will hasten functional and cognitive deterioration. This will also shorten years of independent living and increase the demand for health services. Current available health services are lacking. How and what health services will be provided in the future as individuals with ID age remains unknown. ${ }^{43}$

In this study, different risk factors were correlated with the development of dementia in people with ID, although some evidence was equivocal. Some study findings were contradictory, possibly due to different sample sizes and ages of participants. ${ }^{24}$ In future, validated risk factors may help with early diagnosis and institution of treatment at the most effective time. ${ }^{24}$

Longitudinal assessment of cognition and function in individuals with ID is important to enable early detection of significant deterioration. Such assessment may also provide data for future studies of which symptoms suggest the presence of dementia. Baseline data must be obtained at a time when an individual is healthy. Strydom et $\mathrm{al}^{44}$ recommended that a baseline cognitive level be established before the age of 35 years and be reviewed annually. The use of appropriate measurement tools to monitor the progression of age-related symptoms in people with ID is valuable. Li et al's study ${ }^{20}$ resulted in the development and validation of an instrument with good psychometric properties for screening cognitive changes in a Chinese population with ID.

Early detection allows for therapeutic intervention before any substantial damage to cognition occurs, such as dementia. The delay in receiving appropriate care and identifying the presence of significant cognitive and functional deficits can result in diagnosis of dementia at an already advanced stage. ${ }^{41}$ This delay can further complicate management. Future studies to examine the feasibility and efficacy of interventions are recommended in individuals with ID.

\section{Declaration}

The authors have disclosed no conflicts of interest.

\section{References}

1. American Association on Intellectual and Developmental
Disabilities. Definition of intellectual disability. 2013. Available from: http://aaidd.org/intellectual-disability/ definition\#.WJsHrzt97b0. Accessed 27 Feb 2017.

2. Diagnostic and Statistical Manual of Mental Disorders: DSM-IV-TR. Washington, DC: American Psychiatric Association; 2000.

3. Maulik PK, Mascarenhas MN, Mathers CD, Dua T, Saxena S. Prevalence of intellectual disability: a meta-analysis of population-based studies. Res Dev Disabil 2011;32:419-36.

4. Census and Statistics Department, Hong Kong SAR Government. Persons with disabilities and chronic diseases in Hong Kong 2015. Available from: http://www.statistics. gov.hk/pub/B71501FB2015XXXXB0100.pdf. Accessed 27 Feb 2017.

5. Krinsky-McHale SJ, Silverman W. Dementia and mild cognitive impairment in adults with intellectual disability: issues of diagnosis. Dev Disabil Res Rev 2013;18:31-42.

6. Sheehan R, Ali A, Hassiotis A. Dementia in intellectual disability. Curr Opin Psychiatry 2014;27:143-8.

7. Pang M. Survey study on ageing trend of persons with intellectual disabilities 2015 [in Chinese]. Available from: http://www.lwb.gov.hk/eng/other_info/Report\%20of $\% 20$ the\%20Survey\%20Study\%20on\%20Ageing\%20Trend\%20 of\%20PwIDs_c.pdf. Accessed 27 Feb 2017.

8. Burt DB, Primeaux-Hart S, Loveland KA, et al. Aging in adults with intellectual disabilities. Am J Ment Retard 2005;110:268-84.

9. De Vreese LP, Gomiero T, Uberti M, et al. Functional abilities and cognitive decline in adult and aging intellectual disabilities. Psychometric validation of an Italian version of the Alzheimer's Functional Assessment Tool (AFAST): analysis of its clinical significance with linear statistics and artificial neural networks. J Intellect Disabil Res 2015;59:370-84.

10. Corbett A, Husebo BS, Achterberg WP, Aarsland D, Erdal A, Flo E. The importance of pain management in older people with dementia. Br Med Bull 2014;111:139-48.

11. Parker SE, Mai CT, Canfield MA, et al. Updated national birth prevalence estimates for selected birth defects in the United States, 2004-2006. Birth Defects Res A Clin Mol Teratol 2010;88:1008-16.

12. Strydom A, Shooshtari S, Lee L, et al. Dementia in older adults with intellectual disabilities-epidemiology, presentation, and diagnosis. J Policy Pract Intellect Disabil 2010;7:96-110.

13. Wiseman FK, Al-Janabi T, Hardy J, et al. A genetic cause of Alzheimer disease: mechanistic insights from Down syndrome. Nat Rev Neurosci 2015;16:564-74.

14. McCarron M, McCallion P, Reilly E, Mulryan N. A prospective 14-year longitudinal follow-up of dementia in persons with Down syndrome. J Intellect Disabil Res 2014;58:61-70.

15. Lakin KC, Prouty R, Polister B, Coucouvants K. Change in residential placements for persons with intellectual and developmental disabilities in the USA in the last two decades. J Intellect Dev Disabil 2003;28:205-10.

16. Jokinen NS, Janicki MP, Hogan M, Force LT. The middle years and beyond: transitions and families of adults with Down syndrome. J Dev Disabil 2012;18:59-69.

17. Community support and service needs for old people with disabilities. Research Report July 2016. Available from: https://www.legco.gov.hk/yr16-17/chinese/panels/ws/ papers/wscb2-143-1-c.pdf. Accessed 23 Jan 2017.

18. Deb S, Hare M, Prior L, Bhaumik S. Dementia screening 
questionnaire for individuals with intellectual disabilities. Br J Psychiatry 2007;190:440-4.

19. Zeilinger EL, Nader IW, Brehmer-Rinderer B, Koller I, Weber G. CAPs-IDD: Characteristics of assessment instruments for psychiatric disorders in persons with intellectual developmental disorders. J Intellect Disabil Res 2013;57:737-46

20. Li RS, Kwok HW, Deb S, Chui EM, Chan LK, Leung DP Validation of the Chinese version of the dementia screening questionnaire for individuals with intellectual disabilities (DSQIID-CV). J Intellect Disabil Res 2015;59:385-95.

21. Chaplin E, Paschos D, O'Hara J, et al. Mental ill-health and care pathways in adults with intellectual disability across different residential types. Res Dev Disabil 2010;31:458-63.

22. Perry J, Linehan C, Kerr M, et al. The P15-A multinational assessment battery for collecting data on health indicators relevant to adults with intellectual disabilities. J Intellect Disabil Res 2010;54:981-91.

23. Devenny DA, Krinsky-McHale SJ, Sersen G, Silverman WP. Sequence of cognitive decline in dementia in adults with Down's syndrome. J Intellect Disabil Res 2000;44(Pt 6):654-65.

24. Bush A, Beail N. Risk factors for dementia in people with Down syndrome: issues in assessment and diagnosis. Am J Ment Retard 2004;10:83-97.

25. Patel BN, Pang D, Stern Y, et al. Obesity enhances verbal memory in postmenopausal women with Down syndrome. Neurobiol Aging 2004;25:159-66.

26. Farrer MJ, Crayton L, Davies GE, et al. Allelic variability in D21S11, but not in APP or APOE, is associated with cognitive decline in Down syndrome. Neuroreport 1997;8:1645-9.

27. Schupf N, Kapell D, Nightingale B, Rodriguez A, Tycko B, Mayeux R. Earlier onset of Alzheimer's disease in men with Down syndrome. Neurology 1998;50:991-5.

28. Jenkins EC, Velinov MT, Ye L, et al. Telomere shortening in T lymphocytes of older individuals with Down syndrome and dementia. Neurobiol Aging 2006;27:941-5.

29. Schupf N, Sergievsky GH. Genetic and host factors for dementia in Down's syndrome. Br J Psychiatry 2002;180:405-10.

30. Mok KY, Jones EL, Hanney M, et al. Polymorphisms in $B A C E 2$ may affect the age of onset Alzheimer's dementia in Down syndrome. Neurobiol Aging 2014;35:1513.e1-5.

31. Jones EL, Mok K, Hanney M, et al. Evidence that PICALM affects age at onset of Alzheimer's dementia in Down syndrome. Neurobiol Aging 2013;34:2441.e1-5.
32. Hardy J, Crook R, Perry R, Raghavan R, Roberts G. ApoE genotype and Down's syndrome. Lancet 1994;343:97980

33. Royston MC, Mann D, Pickering-Brown S, et al. Apolipoprotein E epilson 2 allele promotes longevity and protects patients with Down's syndrome from dementia. Neuroreport 1994;5:2583-5.

34. Wisniewski T, Morelli L, Wegiel J, Levy E, Wisniewski HM, Frangione B. The influence of apolipoprotein E isotypes on Alzheimer's disease pathology in 40 cases of Down's syndrome. Ann Neurol 1995;37:136-8.

35. Kuo YM, Emmerling MR, Bisgaier CL, et al. Elevated lowdensity lipoprotein in Alzheimer's disease correlates with brain abeta 1-42 levels. Biochem Biophys Res Commun 1998;252:711-5.

36. Launer LJ, White LR, Petrovitch H, Ross GW, Curb JD. Cholesterol and neuropathologic markers of AD: a population-based autopsy study. Neurology 2001;57:144752.

37. Zigman WB, Schupf N, Jenkins EC, Urv TK, Tycko B, Silverman W. Cholesterol level, statin use and Alzheimer's disease in adults with Down syndrome. Neurosci Lett 2007;416:279-84.

38. Puglielli L, Tanzi RE, Kovacs DM. Alzheimer's disease: the cholesterol connection. Nat Neurosci 2003;6:345-51.

39. Wolozin B. Cholesterol and the biology of Alzheimer's disease. Neuron 2004;41:7-10.

40. Nieuwenhuis-Mark RE. Diagnosing Alzheimer's dementia in Down syndrome: problems and possible solutions. Res Dev Disabil 2009;30:827-38.

41. Heller T, Fisher D, Marks B, Hsieh K. Interventions to promote health: crossing networks of intellectual and developmental disabilities and aging. Disabil Health J 2014;7(1 Suppl):S24-32.

42. De Vreese LP, Mantesso U, De Bastiani E, Weger E, Marangoni AC, Gomiero T. Impact of dementia-derived nonpharmacological intervention procedures on cognition and behavior in older adults with intellectual disabilities: a 3-year follow-up study. J Policy Pract Intellect Disabil 2012;9:92-102.

43. Innes A, McCabe L, Watchman K. Caring for older people with an intellectual disability: a systematic review. Maturitas 2012;72:286-95.

44. Strydom A, Hassiotis A, King M, Livingston G. The relationship of dementia prevalence in older adults with intellectual disability (ID) to age and severity of ID. Psychol Med 2009;39:13-21. 